\title{
Näkökulmia rakkauteen
}

Tähän Idäntutkimuksen Rakkaus-teemanumeroon kutsuimme kirjoituksia, joissa teemaa voi lähestyä eri tieteenalojen ja metodien näkökulmasta. Tämä tuottikin mielenkiintoisen yhdistelmän, jossa pääsemme tutustumaan muun muassa tuoksujen merkitykseen Mihail Kuzminin poetiikassa Aleksandra Pahomovan artikkelissa ja sijaisvanhemmuuden ammatillistumista koskeviin näkemyksiin nyky-Venäjällä Žanna Tšernovan ja Meri Kulmalan artikkelissa. Lisäksi saamme tästä numerosta lukea esimerkiksi Eero Lahelman kirjoituksen neuvostoloikkarin ja helsinkiläisen leskirouvan kohtaamisesta sekä kolumnisti Mia Tadićin ajatuksia serbien ja Serbian rakastamisesta.

Tämä on viimeinen pääkirjoitukseni Idäntutkimuksen päätoimittajana, joten käytän tässä tilaisuutta kiitoksiin. Ensinnäkin kiitän lehteä kanssani tehnyttä toimituskuntaa kaikesta upeasta työstä ja yhteistyöstä jota olette lehden eteen tehneet - erityiskiitos toimitussihteerinä toimineille Saara Ratilaiselle ja Ira Österbergille. Jari Parkkinen aloittaa puolestaan uutena toimitussihteerinä tästä numerosta alkaen. Kiitos kuuluu tässä kohtaa tietenkin myös lehden kirjoittajille, arvioijille, lukijoille ja muille eri tavoin lehden teossa mukana olleille syksystä 2014 alkaneella päätoimittajakaudellani.

Kun Idäntutkimus täytti 25 vuotta vuonna 2019, kirjoitin siitä, miten olimme juuri alkaneet vastaanottaa käsikirjoituksia Journal.fi-alustan kautta - nyt sähköisen alustan kanssa toimiminen on arkipäivää, vaikka valmis lehti on edelleen vahvasti myös painettu tuote. Lehden 27-vuotisessa historiassa on paljon pitkäaikaista ja pysyväksi muodostunutta, kuten teemanumeroiden teko ja yleistajuisen ajankohtaisen sisällön kuten kirja-arvioiden ja taidejuttujen julkaiseminen tieteellisten artikkeleiden rinnalla. Samalla toimituskunnan kanssa ja lehteä julkaisevan Venäjän ja Itä-Euroopan tutkimuksen seuran VIETSin tuella on tehty kehitystyötä lehden kiinnostavuuden ja uusiutumisen eteen.

Idäntutkimus on näiden seitsemän mukanaolovuoteni aikana muun muassa saanut TSV:n vertaisarviointitunnuksen. Koneen Säätiön apurahat vuosina 2015-2017 mahdollistivat esimerkiksi kehittämistyöpajoja ja internetsivujen siirron Journal.fi:hin. Olemme niin sanotun normaalin julkaisuprosessin ohessa tässä vuosien varrella tehneet ulkoasu-uudistuksen ja päivittäneet juttuluokkia, siirtäneet lehden koko arkiston Journal.fi-alustalle ja hankkineet 
Idäntutkimuksen sivuille ajankohtaisten lehden kohdemaista kotoisin olevien nykytaiteilijoiden esittelyitä. Tässä numerossa esittelemme Bulgariasta kotoisin olevan taiteilijan Biljana Furnadžijevan, jonka tuotantoa on myös tämänkertainen lehden kansikuva. Toinen tähän numeroon venäjästä käännetyistä tieteellisistä artikkeleista on saanut suomenkielisen muotonsa säännölliseksi muotoutuneesta yhteistyöstä Helsingin yliopiston kääntämisen ja tulkkauksen maisteriohjelman kanssa.

Aika Idäntutkimuksessa on ollut monin tavoin antoisaa ja avartavaa. Nyt on hyvä hetki antaa lehti uuden päätoimittajan Mika Perkiömäen luotsattavaksi ja toivottaa kaikkea hyvää Idäntutkimukselle myös jatkossa!

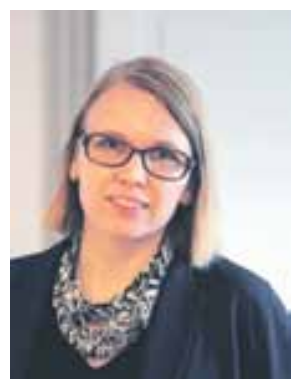

Katja Lehtisari 